\title{
Perilaku Pekerja dan Dampak Penambangan Batu Piring terhadap Lingkungan dan Kesehatan Masyarakat
}

\author{
Prehatin Trirahayu Ningrum $^{1^{*}, \text { Khoiron }^{1}, \text { Rahayu Sri Pujiati }}{ }^{1}$ \\ Fakultas Kesehatan Masyarakat, Uiversitas Negeri Jember, Indonesia \\ (harumfkm@gmail.com,Hp.081330009604)
}

\begin{abstract}
A plate stone mining is one of the mining activities in the district of Jember.This mining is becoming a major commodity for competing in foreign markets (exports). A plate stone that has been processed then utilized to furniture, tables, chairs, decorate walls, and fences. plate Stone is widely used in Japan for house building because it is considered strong and safe from earthquake. The purpose of this study was to determine how the impact of plate stone mining on the environment and public health. This research was a quantitatif descriptive and the population of this study were all stone miners for sample of 33 respondents. Sampling was carried out by using a purposive sampling technique. Variabel studied are the Characteristics of respondents, the Habit ofusing of Personal Protective Equipment, the continuity of the use of masks, working period, work duration, plate stone processing and on an environment impact. The Results of this study was the number of sex workers male $51.5 \%$ and female of $48.5 \%$. As for the age of majority aged between 31-40 years, working period $<5$ years of 57\% with work duration $<8$ hours /days of the 93\%. The process of manually plate stone processing and the impact of mining is changing the of nature. Suggestion of this research is the need for a supervision of government agencies that deal with health and safety.
\end{abstract}

Keywords : Mining, Environment, Public Health

\section{Pendahuluan}

Aktivitas manusia, berazaskan manfaat dan ekonomi serta konservasi lingkungan merupakan suatu hal yang memiliki peranan penting terhadap pembangunan berkelanjutan. Di satu sisi, pembangunan akan meningkatkan kualitas hidup manusia dengan meningkatnya pendapatan masyarakat. Produktivitas kerja dipengaruhi oleh beberapa faktor diantaramya motivasi kerja, latar belakang pendidikan yang sangat menentukan luas tidaknya wawasan seseorang, keterampilan tenaga kerja yang bersangkutan, profesionalisme, profesionalitas, pengalaman, kompetensi kerja, tingkat kesejahteraan, jaminan kontinuitas kerja, jaminan sosial, dan tidak kalah pentingnya adalah kesehatan tenaga kerja (Suma'mur, 2009)

Daerah Jember, mempunyai bentang alam yang unik dan khusus dengan adanya banyak gumuk. Beberapa teori menyatakan bahwa gumuk tersebut merupakan bentukan dari aliran lava gunung Raung, sehingga sebaran dan bentuk gumuk terlihat semakin mengecil ketika jaraknya semakin jauh dari Gunung Raung, seperti di daerah Sukowono, Sumberjambe dan Mayang dijumpai gumuk-gumuk besar dengan ketinggian lebih dari 50 meter, sementara di daerah Wuluhan, Balung dan Kencong ketinggian gumuk hanya sekitar 1-2 meter saja. Besar dan tinggi gumuk bervariasi. Besar gumuk dihitung dari luas bidang dasar yang ditempatinya secara kumulatif bervariasi antara 9,9 Ha sampai 433 Ha setiap kecamatan. Tinggi gumuk berkisar antara 1 meter sampai yang tertinggi 57,5 meter.

Keberadaan gumuk di wilayah ini telah memberikan ciri yang tidak dijumpai di daerah lain di Indonesia. Kehadiran gumuk tersebut memberikan ciri panorama dan sekaligus menambah potensi wilayah. Secara praktis gumuk mempunyai potensi, yaitu untuk kepentingan ilmu pengetahuan, konservasi, pariwisata, usaha tani/hutan rakyat. Sementara potensi yang telah banyak dikembangkan adalah penambangan bahan galian golongan $\mathrm{C}$. 
Selama ini gumuk dimanfaatkan sebagai lahan tegalan, kebun atau digali. Gumuk sebagai lahan tegalan dimanfaatkan untuk penanaman tembakau, ketela pohon, kacang, kedelai, hortikultura, sengon, glirisidae, tanaman buah dan kopi. Lahan di sekitar gumuk umumnya dimanfaatkan untuk penanaman tembakau.

Gumuk juga memberikan manfaat bagi usaha peternakan. Pada daerah gumuk banyak dijumpai masyarakat beternak itik yang memanfaatkan aliran sungai yang bersumber pada gumuk, selain itu juga memanfaatkan satwa alami yang ada pada ekosistem gumuk. Ekosistem gumuk juga mempunyai fungsi sebagai penyimpan air. Mata air di sekitar gumuk umumnya digunakan untuk kepentingan pertanian dan kebutuhan rumah tangga.

Masyarakat dengan tingkat ekonomi yang cukup dengan dukungan lahan pertanian yang subur, ternyata memberikan nilai perlindungan yang lebih baik terhadap keberadaan gumuk. Masyarakat sekitar gumuk merupakan pihak yang paling berkompeten dengan keberadaan gumuk. Mereka adalah pihak yang mendapatkan manfaat dan juga mendapatkan ancaman jika gumuk mengalami penurunan fungsi akibat kerusakan.

Selain itu gumuk ini juga dapat memberikan hasil dari pertambangan yaitu batu piring. Cadangan batu piring sebesar $7.000 .000 \mathrm{~m}^{3}$ berupa gunung batu yang setelah ditambang dipotong-potong sesuai dengan kebutuhan pasar. Batu piring yang telah diproses ini selanjutnya dimanfaatkan untuk mebel air meja dan kursi), penghias dinding tembok, pagar (banyak digunakan di Jepang dalam bangunan rumah karena dinilai kuat dan tahan gempa). Komponen bahan bangunan rumah baik interior maupun eksterior seringkali juga memanfaatkan bahan tambang ini karena bila cuaca panas maka ruangan sejuk dan sebaliknya, tidak licin dan tidak lumutan serta tahan selama bertahun-tahun. Limbah batu piring ini juga masih bias dimanfaatkan sebagai bahan batu cor. Batu piring sebagai bahan bangunan sangat terkenal di indonesia bahkan sampai ke manca negara khususnya negara Malaysia, Singapore, Tiongkok dan Jepang. Salah satu pertambangan batu piring yang ada di Jember adalah di daerah batu piring kawasan Jelbuk. Pertambangan batu piring ini adalah primadona penghasilan bagi masyarakat Jember (Bappekap Jember, 2010)

Penambangan batu piring ini juga dapat memberikan dampak terhadap lingkungan dan kesehatan manusia. Dampak pada lingkungan yaitu pencemaran lingkungan dari hasil limbah yang dihasilkan, sedangkan pada manusia akan berdampak pada kesehatannya. Gangguan kesehatan akibat lingkungan kerja pada penambang batu piring salah satunya adalah terjadinya gangguan fungsi paru para pekerja dan masyarakat. Berbagai aktivitas yang dapat mencemari udara seperti debu yang dihasilkan dari tanah maupun batu piring. Pengaruh pemaparan debu terhadap tenaga kerja dapat mengakibatkan gangguan antara lain kenikmatan kerja, iritasi baik pada mata maupun pada saluran pernapasan dan gangguan fungsi paru. Untuk itu diperlukan kajian lebih lanjut tentang analisis mengenai dampak lingkungan terhadap kesehatan pada pekerja penambang batu piring di Kabupaten Jember. Hasil dpenelitian yang dilakukan (Triananda, 2014) didapatkan bahwa risiko dari kegiatan pertambangan batu piring di desa bedadung meliputi risiko kerusakan dan pencemaran lingkungan, risiko kecelakaan kerja bagi pekerja tambang serta risiko penurunan nilai moralitas warga. Longsor dan pencemaran udara merupakan risiko tertinggi dari kegiatan pertambangan, sementara dampak yang telah terjadi selama kegiatan pertambangan berlangsung ialah dampak negatif dan positif. Dampak negatif yang terjadi adalah perubahan bentang lahan, pencemaran lingkungan dan rusaknya infrastruktur jalan. Dampak positif yang terjadi adalah membuka lapangan kerja baru, mengurangi jumlah pengangguran dan menambah penghasilan warga sekitar.

\section{Metode penelitian}

Jenis penelitian ini adalah deskriptif dengan pendekatan kuantitatif. Populasi penelitian ini adalah semua pekerja yang 
berada di tempat penambangan batu piring sekaligus menjadikan sampel dalam penelitian sebanyak 33 responden. Teknik pengambilan sampel yang digunakan pada penelitian ini menggunakan metode purposive sampling. Variabel dalam penelitian ini adalah karakteristik respoden, kebiasaan menggunakan APD, kontinuitas penggunaan masker, masa kerja, lama kerja, proses pengolahan batu piring, dan dampak terhadap lingkungan. Analisis dengan menggunakan deskriptif dan penyajian data dengan menggunakan tabel. Kriteria inklusi adalah bersedia menjadi responden, berada di tempat kerja saat dilakukan penelitian. Sedangkan kriteria eksklusinya adalah responden tidak berada di tempat kerja saat dilakukan penelitian.

\section{Hasil dan pembahasan}

\subsection{Hasil penelitian}

Data hasil penelitian tersaji pada table 1, table 2, dan table 3 .

Tabel 1. Karakteristik Responden

\begin{tabular}{|c|c|c|c|c|c|c|c|c|c|}
\hline \multirow[t]{3}{*}{ No } & \multirow{3}{*}{$\begin{array}{c}\text { Tempat } \\
\text { penambanga } \\
\mathbf{n}\end{array}$} & \multicolumn{4}{|c|}{ Jenis kelamin } & \multicolumn{4}{|c|}{ Umur } \\
\hline & & \multicolumn{2}{|c|}{ Laki-laki } & \multicolumn{2}{|c|}{ Perempuan } & \multicolumn{2}{|c|}{ 20-30 } & \multicolumn{2}{|c|}{$31-40$} \\
\hline & & $\sum$ & $\%$ & $\sum$ & $\%$ & $\sum$ & $\%$ & $\sum$ & $\%$ \\
\hline 1 & Pakusari & 4 & 23,5 & 16 & 100 & 2 & 16,6 & 18 & 85,7 \\
\hline 2 & Sumbersari & 3 & 17,6 & 0 & - & 3 & 25 & 0 & - \\
\hline 3 & Patrang & 8 & 47 & 0 & - & 5 & 41,7 & 3 & 14,3 \\
\hline 4 & Kalisat & 2 & 11,7 & 0 & - & 2 & 16,6 & 0 & - \\
\hline Tota & & 17 & & 16 & & 12 & & 21 & \\
\hline
\end{tabular}

Berdasarkan Tabel 1. Hasil penelitian yang dilakukan pada 33 responden menunjukkan bahwa responden yang berjenis kelamin lakilaki sebanyak 17 responden $(51,5 \%)$ dan responden berjenis kelamin perempuan sebanyak 16 responden $(48,5 \%)$, sedangkan untuk umur responden didapatkan bahwa responden yang berumur sebagian umur responden pada rentang 31-40 tahun, yaitu sebanyak 21 responden $(63,6 \%)$.

Hasil penelitian tentang penggunaan Alat Pelindung Diri (APD) pada pekerja pertambangan batu piring yang berada di Kecamatan Pakusari, Sumbersari, Patrang dan Kalisat semua responden menyatakan tidak pernah menggunakan alat pelindung diri untuk menghindari dan mengurangi dampak negatif dari debu dan serpihan batu piring.

Pekerja yang bekerja berada di lingkungan udara yang tidak sehat (banyak pencemaran) dalam waktu yang lama, memiliki risiko tinggi terkena penyakit diantaranya dapat mengakibatkan terjadinya gangguan faal paru yang timbul setelah terpajan debu selama 5 - 25 tahun, sedangkan untuk gangguan paru restriktif ringan dapat terpajan debu kurang dari 1 tahun. Lama kerja juga dapat mempengaruhi kesehatan pekerja pertambangan batu piring.

Tabel 2. Masa kerja dan Lama kerja pada Pekerja Pertambangan Batu Piring

\begin{tabular}{|c|c|c|c|c|c|c|c|c|c|}
\hline \multirow[t]{3}{*}{ No } & \multirow{3}{*}{$\begin{array}{c}\text { Tempat } \\
\text { penambangan }\end{array}$} & \multicolumn{4}{|c|}{ Masa Kerja } & \multicolumn{4}{|c|}{ Lama Kerja } \\
\hline & & \multicolumn{2}{|c|}{$\geq 5$ tahun } & \multicolumn{2}{|c|}{$<5$ tahun } & \multicolumn{2}{|c|}{$>8$ jam } & \multicolumn{2}{|c|}{$\leq 8$ jam } \\
\hline & & $\sum$ & $\%$ & $\sum$ & $\%$ & $\sum$ & $\%$ & $\sum$ & $\%$ \\
\hline 1 & Pakusari & 12 & 85,7 & 8 & 42,1 & 2 & 100 & 18 & 58 \\
\hline 2 & Sumbersari & 0 & - & 3 & 15,7 & 0 & - & 3 & 9,7 \\
\hline 3 & Patrang & 0 & - & 8 & 42,1 & 0 & - & 8 & 25,8 \\
\hline
\end{tabular}


ISSN : 2354-5852

e-ISSN : 2579-5783

\begin{tabular}{lcccccccc}
\hline $4 \quad$ Kalisat & 2 & 14,3 & 0 & - & 0 & - & 2 & 6,4 \\
Total & 14 & & 19 & & 2 & & 31 & \\
\hline
\end{tabular}

Berdasarkan Tabel 2 data hasil penelitian didapatkan bahwa responden yang masa kerjanya $\geq 5$ tahun sebanyak 14 responden $(42,4 \%)$ dan responden masa kerjanya $<5$ tahun sebanyak 19 responden $(57,5 \%)$. Lama kerja/durasi kerja responden didapatkan bahwa responden yang lama kerjanya $>8$ jam sebanyak 2 responden $(6 \%)$ dan responden yang lama kerjanya $\leq 8$ jam sebanyak 31 responden $(94 \%)$.

Kebiasaan menggunakan masker merupakan perilaku pekerja dalam menggunakan masker sebagai alat pelindung diri pada saat bertugas di dalam pabrik sehingga pekerja merasa aman dari bahaya terutama debu yang masuk ke saluran pernapasan.

Tabel 3. Kebiasaan Menggunakan Masker

\begin{tabular}{|c|c|c|c|c|c|}
\hline \multirow[t]{3}{*}{ No } & \multirow{3}{*}{$\begin{array}{c}\text { Tempat } \\
\text { penambangan }\end{array}$} & \multicolumn{4}{|c|}{ Kebiasaan Menggunakan Masker } \\
\hline & & \multicolumn{2}{|c|}{ Menggunakan Masker } & \multicolumn{2}{|c|}{ Tidak Menggunakan Maskeı } \\
\hline & & $\sum$ & $\%$ & $\sum$ & $\%$ \\
\hline 1 & Pakusari & 0 & - & 20 & 62,5 \\
\hline 2 & Sumbersari & 1 & 100 & 2 & 6,2 \\
\hline 3 & Patrang & 0 & - & 8 & 25 \\
\hline 4 & Kalisat & 0 & - & 2 & 6,2 \\
\hline \multicolumn{2}{|c|}{ Total } & 1 & & 32 & \\
\hline
\end{tabular}

Berdasarkan Tabel 3 data hasil penelitian didapatkan bahwa responden yang memiliki kebiasaan menggunakan masker sebanyak 1 responden (3\%) dan responden yang tidak menggunakan masker sebanyak 32 responden (97\%).

\subsection{Pembahasan}

Berdasarkan wawancara yang telah dilakukan pada pekerja, semua pekerja mengaku enggan menggunakan APD sekalipun itu disediakan karena menganggap APD hanya akan mempersulit pekerjaan mereka dan membuat mereka semakin tidak leluasa bekerja. Hal ini tentu saja sangat memprihatinkan karena tingkat kesadaran masyarakat tentang kesehatan masih sangat rendah. Jadi, mungkin karena hal itu juga pihak perusahaan enggan menyediakan APD. Apabila pekerja ingin menggunakan APD maka pekerja harus membeli sendiri APD yang dibutuhkan. Pekerja menyatakan bahwa mereka tidak memiliki uang yang cukup untuk membeli APD sehingga mereka tidak pernah menggunakan APD. Tidak tertibnya untuk menggunakan masker pada pekerja saat bekerja di pertambangan batu piring ini merupakan kebiasaan yang sudah sangat biasa terjadi pada para pekerja di industri lainnya. Hasil penelitian ini sama dengan hasil penelitian yang di lakukan oleh Damayanti T, dkk. menyebutkan dari 182 responden terdapat 84 responden $(46,2 \%)$ yang mempunyai kebiasaan buruk dalam penggunaan masker (Damayanti, dkk, 2007)

APD yang baik adalah yang memenuhi standar keamanan dan kenyamanan bagi pekerja (Safety and Acceptation). Apabila pekerja memakai APD merasa kurang nyaman dan penggunaannya kurang bermanfaat bagi pekerja, pekerja tersebut akan enggan memakainya, walaupun memakai karena terpaksa/hanya berpura-pura sebagai syarat agar masih diperbolehkan untuk bekerja atau menghindari sanksi perusahaan. APD yang tepat bagi tenaga kerja yang 
berada pada lingkungan kerja dengan paparan debu berkonsentrasi tinggi adalah masker untuk melindungi debu atau partikel-partikel yang lebih kasar masuk ke dalam saluran pernapasan, terbuat dari bahan kain dengan ukuran pori-pori tertentu dan respirator pemurni udara, membersihkan udara dengan cara menyaring atau menyerap kontaminan toksinitas rendah sebelum memasuki sistem pernapasan (Habsari, 2003).

Kerja fisik apabila kerja yang berat dan monoton yang dilakukan di tempattempat berdebu dalam waktu yang lama tanpa disertai dengan rotasi kerja, istirahat dan rekreasi yang cukup, akan berakibat terjadinya di suatu daerah berdebu maka kapasitas paru seseorang akan semakin menurun. Menurut Keputusan Menteri Tenaga Kerja dan Transmigrasi No. 102/MEN/VI/2004 tentang waktu kerja lembur mengatakan hari kerja dalam sehari adalah 8 jam/hari. Apabila lebih dari 8 jam maka seseorang dalam bekerja dapat dikatakan lembur. Semakin banyak seseorang lembur dalam mengerjakan pekerjaannya maka akan semakin mudah seseorang tersebut dalam keadaan yang tidak sehat karena tenaga terforsir sehingga presentase untuk terjadinya fungsi paru juga semakin banyak (Kepmenakertrans, 2004).

Jam kerja, waktu Istirahat kerja, waktu lembur diatur dalam pasal 77 sampai pasal 85 Undang-Undang No.13 tahun 2003 tentang Ketenagakerjaan (UU RI, 2003). Rata-rata pekerja tambang di Kecamatan Pakusari bekerja selama 9-10 jam. Jumlah jam kerja yang lebih dari 8 jam perhari sudah tidak memenuhi persyaratan jumlah jam kerja maksimal untuk pekerja. Lama kerja pekerja Perusahaan Putra batu Alam di Kecamatan Sumbersari yakni selama 6,5 jam dan waktu istirahat 1,5 jam. Jumlah jam kerja yang kurang dari 8 jam perhari sudah memenuhi persyaratan jumlah jam kerja maksimal untuk pekerja.Untuk Perusahaan U.D Slawu Jaya di Kecamatan Patrang hanya menetapkan jam mulai bekerja dan pekerjalah yang menentukan jam istirahat dan jam pulang kerja sendiri. Para pekerrja tersebut akan pulang apabila sudah menggiling batu piring sebanyak kurang lebih 3-3,5 $\mathrm{m}^{3}$. Pekerja pemotong batu lempeng pada UD Hibah Alam di Kecamatan Kalisat seluruhnya bekerja dengan jam kerja kurang dari 8 jam per hari. Pada UD Hibah Alam diberlakukan 2 shift kerja, yaitu shift pagi dari jam 8 pagi hingga jam 3 sore dan shift malam dari jam 4 sore hingga jam 12 dini hari dengan waktu istirahat 1 jam untuk masingmasing shift. Jumlah jam kerja yang kurang dari 8 jam perhari sudah memenuhi persyaratan jumlah jam kerja maksimal untuk pekerja. Namun, jam istirahat yang hanya satu jam dirasa kurang sesuai dengan jam kerja yang cukup panjang.

Setiap kegiatan industri selalu menggunakan teknologi, baik teknologi yang canggih ataupun sederhana. Efek samping penggunaan teknologi dapat mengganggu tatanan kehidupan dan lingkungan hidup, khususnya penggunaan teknologi yang dapat berdampak negatip pada tenaga kerja (Depkes RI, 1994). Pekerja yang berada pada lingkungan kerja dengan kadardebu tinggi dalam waktu lama memiliki risiko tinggi terkena obstruksi paru (Wardhana, 2001). Berdasarkan studi penelitian yang dilakukan oleh Sugeng AM, dkk menunjukkan bahwa masa kerja lebih dari 10 tahun mempunyai risiko terjadinya obstruksi paru pada pekerja industri yang berdebu (Sugeng, 2003). Sesuai dengan penelitian Mila SM, berdasarkan perhitungan chi-square pada tingkat signifikansi $\alpha: 0,05$ dan df: 1 diperoleh $\mathrm{x}^{2}$ sebesar 10,139 sedangkan $\mathrm{x}^{2}$ dalam tabel 3,481 $\left(\mathrm{x}^{2}\right.$ hitung $>\mathrm{x}^{2}$ tabel, dan $\mathrm{p}$ sebesar $0,001(p<0,05)$ yang artinya ada hubungan antara masa kerja dengan kapasitas fungsi paru, di peroleh keeratan hubungan sebesar 0,523 yang artinya ada hubungan yang cukup kuat antara masa kerja dengan kapasitas fungsi paru. Kelainan ini sesuai dengan 
teori bahwa makin lama terpajan lingkungan udara yang tercemar maka makin besar kemungkinan untuk terjadi gangguan faal paru (Mila, 2018).

Alat pelindung diri yang baik adalah APD yang memenuhi standar keamanan dan kenyamanan bagi pekerja (safety and acceptation), apabila pekerja memakai APD merasa kurang nyaman dan penggunaannya kurang bermanfaat bagi pekerja, pekerja tersebut akan enggan memakainya, walaupun memakai karena terpaksa/ hanya berpura-pura sebagai syarat agar masih diperbolehkan untuk bekerja atau menghindari sanksi perusahaan. Salah satuAPD yang penting bagi pekerja di pertambangan yang digunakan untuk melindungi fungsi paru adalah masker. Masker berfungsi untuk mengurangi polutan yang masuk lewat rongga pernafasan. Masker yang ideal adalah masker yang mampu meminimalkan udara kotor yang masuk ke tubuh dan tidak mengganggu pernafasan. Banyaknya polutan baik dari asap kendaraan maupun debu perlu disaring. Masker yang aman harus mengandung karbon aktif yang berfungsi sebagai filter dan absorber sehingga penyaringan udara lebih baik. APD sangat sederhana adalah alat pelindung yang dikenakan (dipakai) oleh tenaga kerja secara langsung untuk tujuan pencegahan kecelakaan atau terjadinya penyakit akibat kerja yang disebabkan oleh aneka faktor yang ada (timbul) dilingkungan kerja (M. Suritno, 2008)

APD yang yang diperlukan untuk dikenakan selama bekerja di bagian kerja tertentu adalah: 1) respirator, sarung tangan, sepatu boot, pelindung mata, masker. Hasil penelitian ini berbanding terbalik dengan hasil penelitian Tadesse S, dkk, untuk tingkat pemanfaatan personal protective equipment (PPE) pada pekerja tekstil di Hawassa Town Southern Ethiopia dua kali lebih tinggi dari pada pekerja yang tidak memakai alat pelindung diri. Namun, ini tidak berarti bahwa tidak perlu untuk memperkuat program keselamatan sebagai proporsi yang signifikan dari para pekerja masih melakukan tidak menggunakan semua APD yang diperlukan selama bekerja. Intervensi untuk mempromosikan pemanfaatan APD harus fokus pada daerah, seperti durasi layanan, ketersediaan APD, kehadiran pergeseran kerja, dan pengendalian penyalahgunaan zat (Tedesse, 2016)

Dalam bekerja seluruh pekerja tidak menggunakan masker. Alasan mereka tidak menggunakan masker sangat beragam, mereka mengatakan bahwa masker itu ribet, hanya bisa mengganggu dan harganya relatif mahal, sedangkan yang lain berasalan tidak biasa menggunakan masker, tidak membutuhkan ataupun merasa sedikit terpapar debu. Memang pihak perusahaan juga tidak menyediakan masker atau alat pelindung diri yang lain. Debu yang terhirup oleh pekerja bisa mengakibatkan adanya gangguan kesehatan antara lain yaitu terjadinya penyakit paru-paru salah satunya silikosis. Salah satu pencegahan yang dapat dilakukan adalah dengan penggunaan masker. Hal ini sesuai dengan hasil penelitian Jian yajiang, 2013 dihasilkan bahwa riwayat pekerjaan pada pekerja yang bekerja khusus pada penambangan batu piring selama satu decade didapatkan adanya penyakit silikosis dengan diagnose pasti. ${ }^{13}$ Pemilihan alat-alat pelindung saluran pernapasan harus didasarkan kepada hasil evaluasi terhadap bahaya yang berkaitan dengan pengelompokan pada setiap jenis bahaya baik secara fisik maupun kimia (M Soeripto, 2008)

Sama halnya dengan penelitian yang dilakukan Yulaekah pada pekerja tambang kapur, jenis APD yang paling banyak digunakan oleh responden $(75,86 \%)$ adalah masker, meskipun pada kenyataannya masker yang digunakan adalah kaos (pakaian) (Yulaekah, 2013). Sebagian besar responden $(48,39 \%)$ menyatakan malas menggunakan masker sedangkan $25,81 \%$ responden menyatakan tidak 
tersedia karena memang pengusaha tidak menyediakan APD. Dengan tidak memakai masker maka bisa menyebabkan terjadinya gangguan fungsi paru ataupun penyakit silikosis pada pekerja. Seperti penelitian Nelson didapatkan bahwa dari 19.143 penambang emas yang meninggal karena penyebab eksternal, 16.411 $(85,7 \%)$ yang berkulit hitam dan 2732 $(14,3 \%)$ adalah kulit putih. Proporsi kasar penambang hitam dengan silikosis meningkat sepuluh kali lipat 3$32 \%$; sedangkan untuk yang berulit putih laki-laki sedikit, dari 18 menjadi 22\% (Nelson Gill, 2013)

Pengolahan batu piring juga dilakukan di daerah pertambangan Gumuk Suda Kecamatan Pakusari, jadi tidak ada pengelolaan yang dilakukan oleh pabrik. Limbah yang dihasilkan dari proses pertambangan hanya berupa limbah padat yaitu pecahan batu piring. Namun, pecahan tersebut masih memiliki nilai jual yaitu diolah menjadi batu yang berukuran lebih halus lagi dan dijadikan bahan baku cor untuk bangunan.

Perusahaan Putra Batu Alam di Kecamatan Sumbersari bergerak di bidang pemotongan batu piring. Limbah batu piring dari hasil pemotongan berupa pasir batu piring dan pecahan batu piring. Pecahan batu piring di jual kepada para pemecah batu di sekitar lokasi perusahan untuk dipecah kembali menjadi batu yang ukurannya lebih kecil yang kemudian di jual sedangkan untuk pasir batu piring, hanya di pinggirkan ke tempat yang sekiranya tidak mengganggu. Apabila gunungan pasir telah tinggi maka pemilik perusahaan mengerahkan para pekerjanya untuk mengangkut pasir dan meratakannya di lahan kosong sekitar perusahaan.

U.D Slawu Jaya di Kecamatan Patrang bergerak dalam bidang penggilingan batu piring yang menghasilkan limbah berupa debu. Debu yang dihasilkan ini akan lebih mudah mencemari lingkungan sekitar karena sifatnya yang ringan dan mudah terbang terbawa angin. Pencemaran lingkungan akibat debu ini didukung karena letak U.D Slawu Jaya yang berada dipinggir jalan sehingga memudahkan debu terbang terbawa angin sebagai efek dari laju kendaraan bermotor. U.D Slawu Jayatidak memiliki pengelolaan khusus dalam menangani debu yang dihasilkan dari proses penggilingan. Penggilingan batu piring dilakukan di ruangan terbuka sehingga debu dapat langsung terbang terbawa angin.

U.D Citra Natural Stone di Kecamatan Kalisat bergerak dalam bidang pemotongan batu piring.Limbah yang dihasilkan dari proses pemotongan batu piring di U.D Citra Natural Stone berupa limbah padat dan limbah cair. Limbah padat berupa sisasisa potongan batu piring yang kemudian dipecah menjadi ukuran yang lebih kecil untuk dijadikan batu cor yang laku dijual. Sedangkan limbah cair yang dihasilhan juga tidak mengalami proses pengolahan, limbah cair berasal dari air sisa untuk membasahi batu yang dipotong, dan air tersebut terus mengalir dengan lancar menuju selokan di samping tempat produksi. Air yang merupakan limbah cair bekas pemotongan batu lempeng ini masih dapat dimanfaatkan untuk diendapkan dan diambil pasirnya.

Aktivitas pertambangan memang dapat berisiko merusak tatanan alam, karena lokasi pertambangan yang sudah sangat dalam mengakibatkan air tanah juga ikut keluar. Air tanah tersebut disedot dengan mesin dan dialirkan langsung ke sungai sekitar pertambangan. hal ini mengakibatkan terjadinya semakin banyak sedimentasi di daerah sungai tersebut dan mengakibatkan sungai menjadi semakin keruh karena tekanan yang dihasilkan dari keluarnya air tersebut dari selang pompa air. Sedangkan pada pertambangan dapat merusak tatanan alam, dimana jika air tanah terus dipompa keluar, maka keseimbangan pada daerah tersebut menjadi terganggu. Hal ini sesuai dengan 
penelitian Hilson $G$ dan Vost HVD dampak lingkungan yang terjadi adalah tiga masalah lingkungan yang terkait dengan kegiatan pertambangan emas skala kecil: (1) pencemaran merkuri; (2) air asam tambang (AMD) dari tailing; dan (3) degradasi lahan pertama dua dari tiga besar tersebut masalah lingkungan dapat diperbaiki melalui inisiatif teknologi, tapi yang ketiga (degradasi lahan) membutuhkan pendekatan yang lebih luas (Hilson Gavin, 2002).

Keadaan yang berbahaya lainnya adalah, jalan yang digunakan oleh para kuli angkut yang rawan longsor. Oleh karena jalan tersebut terbuat dari tumpukan pecahan batu sisa pertambangan, jadi keseimbangan dari jalan tersebut sangat rendah. Jika ada aktivitas penambangan lagi di bawahnya, maka jalan di atasnya dapat berpotensi longsor. Namun, tidak ada upaya perbaikan dari warga sekitar dan para pekerja sendiri. Jalan menuju pertambangan keadaannya becek dan licin, jadi untuk pengendara sepeda motor sedikit berbahaya.

Proses pengolahan batu piring memberikan dampak negatif untuk lingkungan yaitu pencemaran fisik (kebisingan) dan pencemaran udara khususnya bagi penduduk yang berada di dekat lingkungan perusahaan. Sementara itu, pencemaran udara berupa debu yang berasal dari proses pengolahan batu piring. Meskipun selama proses pemotongan sudah menggunakan air sumur yang bertujuan untuk membasahi batu dan diharapkan debu yang dihasilkan dapat dikurangi. Namun, proses pengolahan masih tetap menghasilkan debu yang dapat mencemari udara di sekitar. Hal ini dapat menyebabkan gangguan kesehatan masyarakat berupa batuk dan pusing.

\section{Kesimpulan}

Kesimpulan penelitian adalah pekerja yang bekerja di pertambangan batu piring kebanyakan berjenis kelamin laki-laki tetapi perempuan juga menjadi pekerja dengan rata-rata usia 31-40 tahun, dengan masa kerja sebagian besar $\leq 5$ tahun dengan lama kerja $\leq 8$ jam/hari. Proses pengolahan sebagian besar masih secara manual dan dampak dari pertambangan batu biring ini adalah adanya perubahan tatalahan alam. Saran penelitian ini adalah untuk perusahaan sebaiknya menyediakan fasilitas APD untuk keamaan pada saat bekerja, dan untuk instansi pemerintah diperlukan adanya pengawasan secara berkala untuk kesehatan keselamatan kerja dan pengawasan kepada alam sehingga pertambangan batu biring ini tidak berdampak besar pada alam yang akhirnya berdampak ke manusia.

\section{Daftar pustaka}

Bappekab Jember., 2010. Batu Piring. [diakses, 28 november 2011]. Availableat:

http://bappeda.jemberkab.go.id /index.php?option $=$ com conte nt\&view $=$ article \&id $=79$ : batupiring \& catid $=46$ :tambang\& Ite mid $=91$

Damayanti, T, Yunus, F., Ikhsan, M., Sutjahhyo K. 2007. Hubungan Penggunaan Masker dengan Gambaran Klinis, Faal Paru dan Foto Toraks Pekerja Terpajan Debu Semen. Majalah Kedokteran Indonesia

Depkes RI. 1994. Upaya Kesehatan Kerja Sektor Informal di Indonesia. Materi Upaya Kesehatan Kerja. Jakarta

Habsari ND. 2003. Penggunaan APD bagi Tenaga Kerja. Bunga Rampai Hiperkes dan Keselamatan Kerja. Semarang : Badan Peberbit UNDIP

Hilson Gavin, Vorst RVD. 2002. Technology, Managerial, and Policy Initiatives for Improving Environmental Performance in Small-Scale Gold Mining Industry. Jurnal Environment Management

Jiyang yajian. 2013. A Stone Miner With Both Silicosis and Constrictive Pericarditis: Case 
Report and Review of the Literature. BioMed Central Pulmonary Medicine

Keputusan Menteri Tenaga Kerja dan Transmigrasi No. 102/MEN/VI/2004 tentang waktu kerja lembur. Jakarta : Menteri Tenaga Kerja dan Transmigrasi Republik Indonesia

M. Soeripto. 2008. Higiene Industri. Jakarta: Balai Penerbit FKUI.

Mila SM. 2006. Hubungan antara Masa Kerja, Pemakaian Alat Pelindung Pernafasan (Masker) pada Tenaga Kerja Bagian Pengamplasan dengan Kapasitas Fungsi Paru PT. Accent House Pecangaan Jepara [Skripsi]. Semarang : Universitas Diponegoro

Nelson Gill. 2013. Occupational Respiratory Diseases in the South African Mining Industry. Global Health Action

Sugeng AM, RMS Jusuf, Adriana P. 2003. Bunga Rampai Hiperkes dan Kesehatan Kerja. Semarang: Badan Penerbit Universitas Diponegoro

Suma'mur. 2009. Hygiene Perusahaan dan Kesehatan Kerja (HIPERKES). Jakarta : Sagung Seto

Tedesse, S., Kelaye, T., Assefa, Y. 2016. Utilization of Personal Protective Equipment and Associated Factors Among Textile Factory Workers at Hawassa Town, Southern Ethiopia. Journal of Occupational Medicine and Toxicology

Triananda Guntur. Analisis Risiko Lingkungan Kegiatan Pertambangan Batu Piring Di Kabupaten Jember . [Skripsi]. Fakultas Kesehatan Masyarakat Universitas Jember.

Undang-undang Republik Indonesia Nomor 13 tahun 2003 tentang
Ketenagakerjaan. Jakarta : Presiden Republik Indonesia

Wardhana. AW. 2001. Dampak Pencemaran Lingkungan. Yogyakarta : ANDI

Yulaekah, S. 2007. Paparan Debu Terhirup dan Gangguan Fungsi Paru pada Pekerja Industri Batu Kapur (Studi di Desa Mrisi Kecamatan Tanggungharjo Kabupaten Grobogan) [Tesis]. Semarang: Program Pasca Sarjana Universitas Diponegoro 